\title{
Germination behaviour of four mediterranean Cistus L. species in relation to high temperature
}

\author{
Domenica Scuderi, Rosa Di Gregorio, Stefania Toscano, Carla Cassaniti, Daniela Romano
}

Department of Horticulture and Food Technology, University of Catania, Via Valdisavoia 5, 95123 Catania, Italy, e-mail: dromano@unict.it

\begin{abstract}
Cistus is one of the most characteristic genera of the Mediterranean flora. These species, natives of lands surrounding the Mediterranean Sea, are present in scrubland and garigue on siliceous ground and often on acid soil; seven species in particular are founded in Sicily. The adaptation of the genus to Mediterranean environments is evident from ecological characteristics such as firedependent seed germination; the heat generated by fire is in fact a key germination input.

In this view, two experiments were performed to study the effects of high temperature on germination of four Cistus species (C. creticus L., C. crispus L., C. monspeliensis L., C. salviifolius L.). In the first, in relation to untreated control, 7 different high temperature pre-treatments (from $70^{\circ} \mathrm{C}$ to $130^{\circ} \mathrm{C}$ ) for different timings (from 1 to 10 minutes) were analysed in relation to two sowing strategies (soon after the seed collection and after a 6 month period at $5^{\circ} \mathrm{C}$ to simulate the winter season effects). The pre-treatment with high temperatures can improve the germination; the storage at $5^{\circ} \mathrm{C}$ to simulate the winter season effects did not modify the germination process. In any case the results showed a species-dependent response. High germination percentage was obtained for $C$. creticus, while a lower germination rate was achieved by $C$. crispus and C. monspeliensis.

In the second experiment, seeds were treated for different periods $\left(80^{\circ} \mathrm{C}\right.$ for $10 \mathrm{~min}, 90^{\circ} \mathrm{C}$ for $5 \mathrm{~min}$ and $100^{\circ} \mathrm{C}$ for $\left.1 \mathrm{~min}\right)$ with high temperature in dry and wet (immersion in distilled water) conditions. Also in this case the responses were strictly linked to the species. Especially C. crispus and C. monspeliensis showed high germination percentage in wet conditions. In all species the wet heat treatments determined an accelerating of process like demonstrated by lower T50 values.
\end{abstract}

Key words: Cistus creticus L., C. crispus L., C. monspeliensis L., C. salviifolius L., pre-germination heating.

\section{Introduction}

Cistaceae is a medium-size family (eight genera, 180 species), distributed in temperate and subtropical regions of the northern hemisphere (Guzman \& Vargas 2009), and showing the highest genus and species diversity in the Mediterranean floristic region. In fact, five of the eight genera (Cistus, Funmana, Halimium, Helianthemum, Tuberaria) are native to this region. Cistus is one of the most characteristic genera of shrubs or subshrubs of the Mediterranean flora (Guzman \& Vargas 2005) and comprises more than 16 species with a circum-Mediterranean distribution (PérezGarcia 1997); Cistus species are characteristic of dry and sunny habitats. Plants are evergreens with profuse and attractive blooms. They are natives of lands surrounding the
Mediterranean Sea and 7 species (C. crispus L., C. creticus L., C. clusii Dunal in DC., C. monspeliensis L., C. parvifolius Lam., C. salviifolius L., C. $x$ varius Pourr.) are present in Sicily (Giardina et al. 2007) in scrubland and garigue on siliceous ground. Some of them, especially $C$. salviifolius and $C$. monspeliensis, are often diffused on acid soil.

The adaptation of the genus to Mediterranean environments is evident from ecological characteristics such as fire-dependent seed germination (Trabaud \& Renard 1999; Delgado et al. 2001), insect-dependent pollination (Talavera et al. 1993), biometrical and leaf anatomical differences between summer and winter habits of Cistus plants (Aronne \& De Micco 2001) that allow these plants to overcome with hot and dry summers (Daget 1977). The seasonal fluctuations in soil moisture are in fact considered 
a limiting factor for growth and productivity of Mediterranean perennial species (Specht 1987).

Cistus plants produce a large crop of seeds every year (Troumbis \& Trabaud 1986) and their regeneration in normal conditions or after fire is realised almost exclusively by seeds (Thanos \& Gheorghiou 1988). The seeds have a primary dormancy imposed by seed coat which, in the natural environment, is eventually released massively by wildfires (Doussi \& Thanos 1994; Quintana et al. 2004). Many Cistus species have been considered as social phyrophyted (sensu Kuhnholtz-Lordat 1938), because they establish in a great number after fire by seed germination (Ferrandis et al. 1999). It is broadly accepted that the high temperatures recorded in soil during a wildfire are the main factor responsible for this germination response, since the thermal shock associated with fire can break down the testa of buried seeds, thus, overcoming physical dormancy (Baskin \& Baskin 1989; Hanley \& Fenner 1998).

Cistus seeds are characterized by the presence of physical dormancy, which, in addition to high seed longevity (Troumbis \& Trabaud 1986) and small size and mass, allow the generation of persistent soil seed banks (Grime 1989). Dormancy is broken down by high temperatures generated by fire and this process leads to high densities of Cistus seedlings in the rainy season following fire (Ferrandis et al. 2001; Bastida \& Talavera 2002).

Post-fire regeneration is a complex process dependent upon factors such as germination strategies of species, their characteristics and fire adaptation, the abundance of seed in both soil and aerial banks, the fire parameters (time of years, size, severity, etc.) (Herrero et al. 2007; Trabaud et al. 1985). Fire intensity is one of the most important factors influencing post-fire regeneration of an ecosystem (Sousa 1984) and is characterised by two factors: exposure time and temperature reached during the fire (Núñez \& Calvo, 2000). To evaluate the germination response after different fire intensities, the thermal shock is considered the most widespread technique to break seed dormancy (Thanos et al. 1989; Herrero et al. 2007). Thermal treatments could be carried out using seeds heated in an oven at different controlled temperatures, with a range of temperature simulating the real conditions of soil during a natural fire, and combining different exposure times (Pérez \& Pita 1996). The modality to heat given (dry or wet high temperature) can modify the seed response to heat treatments (Bacchetta et al. 2008); the high germination value in different species of Cistus were achieved when the seed were put in distilled water at high temperature or in boiling water (Bacchetta et al. 2008).

Previous studies verified that the heat produced by fire lasts for a short time (between five and 15 minutes) and reaches a range of temperatures between $44^{\circ} \mathrm{C}$ and $150^{\circ} \mathrm{C}$ at $2.5 \mathrm{~cm}$ of depth (Trabaud 1979).

The aim of the present study is to evaluate the effect of high thermal treatments and exposure time on the germi- nation of four Cistus species. Two different sowing strategies (soon after that the seed have been collected and after 6 months at $5^{\circ} \mathrm{C}$ to simulate the effect of winter season) were carried out in order to analyze the better period to start the germination. The dry and wet (seed immerged in distilled water) high temperature were evaluated to investigate if the treatment modality can influence the germination process.

\section{Materials and methods}

For both experiments fruits of Cistus were collected in two natural areas of Sicily (Italy): three of them (Cistus creticus L., C. monspeliensis L. and C. salviifolius L.) at Bosco di S. Pietro $\left(37^{\circ} 17^{\prime} \mathrm{N}, 1^{\circ} 26^{\prime} \mathrm{E}\right.$, at $490 \mathrm{~m}$ a.m.s.l.), while fruits of $C$. crispus were collected at Colli San Rizzo $\left(38^{\circ} 11^{\prime} \mathrm{N}, 15^{\circ} 33^{\prime} \mathrm{E}\right.$ at $500 \mathrm{~m}$ a.m.s.l.).

Up to the time of experiments, the seeds were stored in opaque paper bags at constant temperature $\left(5 \pm 1^{\circ} \mathrm{C}\right)$. Before the starting of the trial the 1000 seed weight was calculated. Seed weights of the species varied widely, ranged from 0.66 $\mathrm{g}$ in Cistus creticus to $0.95 \mathrm{~g}$ in C. salviifolius; intermediate weights showed $C$. crispus $(0.78 \mathrm{~g})$ and $C$. monspeliensis $(0.70 \mathrm{~g})$. In all case, except for $C$. salviifolius, these values are typical for the species (Piotto \& Di Noi 2001).

The germination tests were carried out by placing 20 seeds on Waterman No. 2 filter papers moistened daily with de-ionized water inserted in $8-\mathrm{cm}$ diameter Petri dishes (experimental unit). Petri dishes were arranged in a completely randomized design with 4 replicates for each treatment and in a growth chamber at $20^{\circ} \mathrm{C}$ in the dark. This temperature level was adopted basing on previous results of a trial that analysed the effect of $15^{\circ} \mathrm{C}-25^{\circ} \mathrm{C}$ temperature interval (Li Rosi et al. 2008). After the beginning of germination, the germinated seeds were counted and removed from each Petri dish every day, for a period of 60 days. A seed was considered germinated when the radicle emerged $2 \mathrm{~mm}$ from the testa (Come 1970). Final germination percentage was calculated as number of germinated seeds/20x100. Speed and uniformity were quantified using the T50 of germination, that is the time needed for manifestation of half of the final germination calculated according to Salehzade et al. 2009, and the standard errors of means. Separately for each species, on germination percentage, previously subjected to angular transformation, analysis of variance (ANOVA) was carried out to determine the significance of the different treatments.

The experiment 1 has the aim to investigate the influence of pre-heating treatments from $70^{\circ} \mathrm{C}$ to $130^{\circ} \mathrm{C}$ for different period (from 1 to 10 minutes). The trials were started in October and March, one and six months later the seed collection, respectively. In each trial 21 treatments were performed, resulting from a combination of 7 differ- 
ent temperatures $\left(70,80,90,100,110,120,130{ }^{\circ} \mathrm{C}\right)$ and 3 exposure times $(1,5$ and $10 \mathrm{~min})$ plus a control treatment with no thermal treatment.

In the experiment 2 , seeds were treated for different periods $\left(80^{\circ} \mathrm{C}\right.$ for $10 \mathrm{~min}, 90^{\circ} \mathrm{C}$ for $5 \mathrm{~min}$ and $100^{\circ} \mathrm{C}$ for $1 \mathrm{~min}$ ) with high temperature in dry and wet (immersion in distilled water) conditions. The aim was to investigate the influence of dry and wet conditions on germination process of the same four species.

The modalities of trial were the same of experiments 1 and also in this case the trials were replicated two times (in October and March).

\section{Results and discussion}

\subsection{Experiment 1}

The germination of untreated Cistus seeds was generally low (Fig. 1). The main characteristic of Cistus seed is the seed coat hardiness; thus, only a small fraction (quite always less than $20 \%$ except for C. crispus) of a given Cistus seed population (the 'soft' seeds) can germinate, while the rest cannot imbibe water (Thanos \& Georghiou 1988). Pre-germination heat treatments increased the proportion of seed germinating compared with the control treatment. Although differences are clear (often $\mathrm{P}<0.001$ ), their significance cannot be ascertained from the results of threeway ANOVA because the significant interaction between the treatments (Tab. 1).

However Cistus seed germination can be significantly promoted by thermal pre-treatment, like reported by several authors (Hanley \& Fenner 1998; Thanos \& Gheorghiou 1988). The response ranged widely in relation to different species; in our study, especially Cistus creticus showed an higher percentage of germination with the thermal pre-treatment. When seeds were thermally pre-treated for $1-10$ minutes until $100^{\circ} \mathrm{C}$ a significant increase of germination was observed for each trial date. The best results were achieved with the shortest exposure time (1 minute). Prolonged heating and also increasing temperature the total amount of germinating seeds were reduced (Fig. 1).

As previously discussed by many authors, germination, in different ways in relation to the species, is inhibited when temperatures are very high and/or the exposure time is prolonged (Valbuena et al. 1992; Herrànz et al. 2000; Reyes \& Boedo 2001; Reyes \& Traboud 2009). It is probable that the same mechanism that stimulates the germination under certain combinations of time and temperature could also be indirectly responsible for the deterioration of the embryo and its death, above certain temperature thresholds, as observed by Reyes and Trabaud (2009).

The high temperature crack the seed coat, allowing water to filter into the embryo, thus activating germination.
Table 1. Significance of $F$-test ${ }^{(a)}$ for different treatments on the germination and on the time required to achieve $50 \%$ cumulative germination (T50\%) in different Cistus species

\begin{tabular}{|l|l|l|}
\hline Factor & Germination $(\%)$ & T50 (days) \\
\hline Species (S) & $* * *$ & $* * *$ \\
\hline Pre-treatments (PT) & $* * *$ & $* * *$ \\
\hline Trial time (TT) & $* * *$ & $* * *$ \\
\hline S x PT & $* * *$ & $* * *$ \\
\hline S x TT & $* * *$ & $* * *$ \\
\hline PT x TT & $* * *$ & $* * *$ \\
\hline S x PT x TT & $* * *$ & $* * *$ \\
\hline
\end{tabular}

(a) $\mathrm{ns}, *, * *$ and $* * *$, not significant at $\mathrm{P}<0.05,0.01$ or 0.001 , respectively

If the high temperatures are applied for too long time, the heat affects the embryo drying it up to reach a lethal level. In any case the seed germination is better than control in a large range of temperature and exposure time to show an opportunistic strategy of germination, that allow the different species to germinate in a wide range of temperature conditions (Thanos et al. 1992).

Trabaud (1995) has pointed out that these species are not exclusively dependent on fire. It is probable that hardseedness is favourable because it can simultaneously provide embryo protection, seed persistence in the soil (Thompson \& Booth 1993) and an efficient dormancy mechanism (Ferrandis et al. 1999) for the quick detection of suitable conditions for seedling establishment in a warm dry-summer Mediterranean climate.

The seed storage at $5{ }^{\circ} \mathrm{C}$ for six months, to simulate the winter season effects, was able to increase the germination percentage only in $C$. creticus and $C$. salviifolius. In the latter reductions in germination percentage were observed in quite all heat pre-treatments.

The heat pre-treatments has not modified the time needed for manifestation of half of the final germination level in quite all species (Figs. 2-5). Also for this parameter there were differences in relation to the species. In C. monspeliensis (Fig. 4) the T50 of the control was lower in relation to the different pre-treatments, at least for the October trial. This result could be justified if we suppose that, in absence of heat pre-treatment, only the 'soft' seeds are able to quickly germinate and hence in a very short time. In the other treatments the germination stimulus determined by heat temperature allowed to germinate a greater number of seeds but in a longer time. In any case, only little differences are showed and without a clear trend. 
Cistus creticus L.
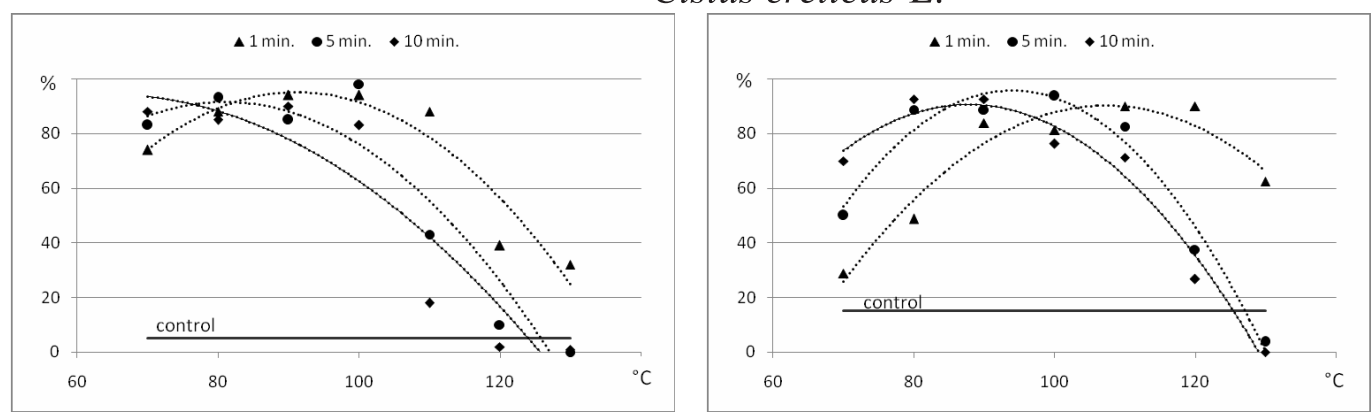

Cistus crispus L.
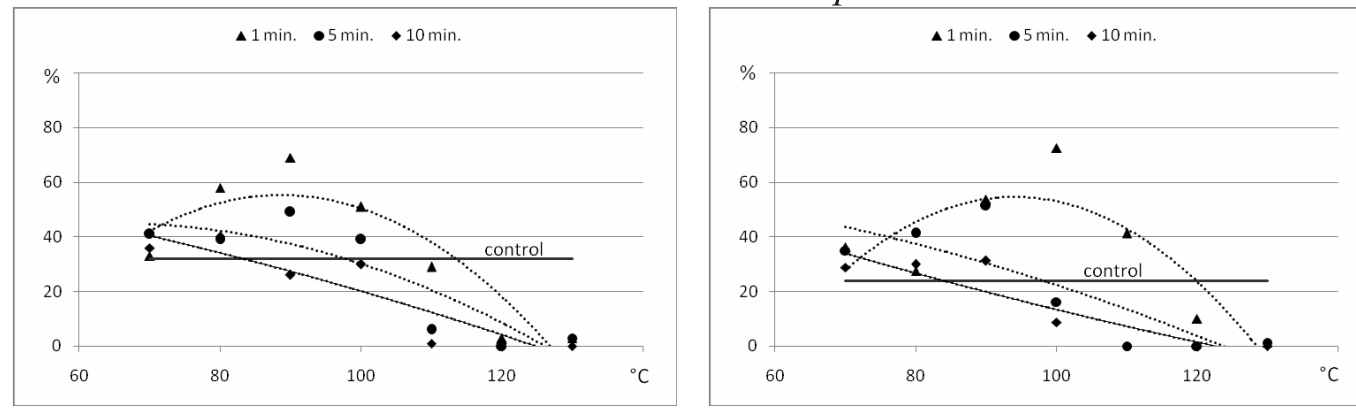

Cistus monspeliensis L.
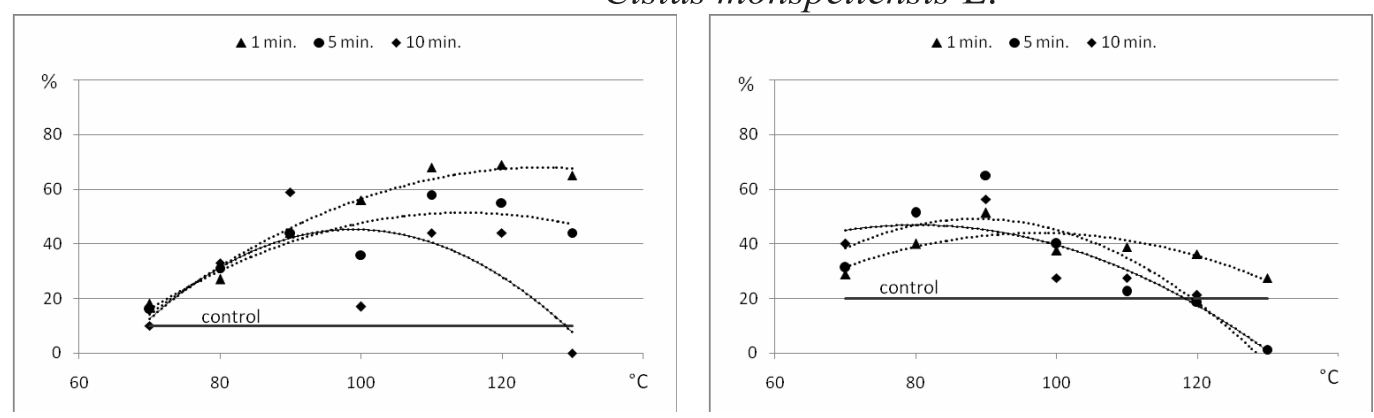

Cistus salviifolius L.
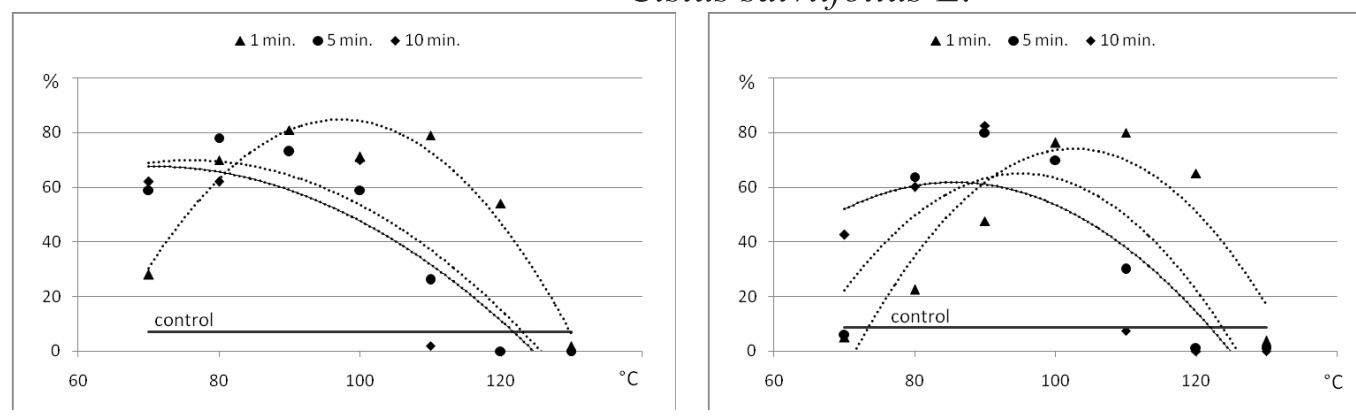

Figure 1. Seed germination (\%) in relation to treatments in the trial started in October (on the left) and in March (on the right) 

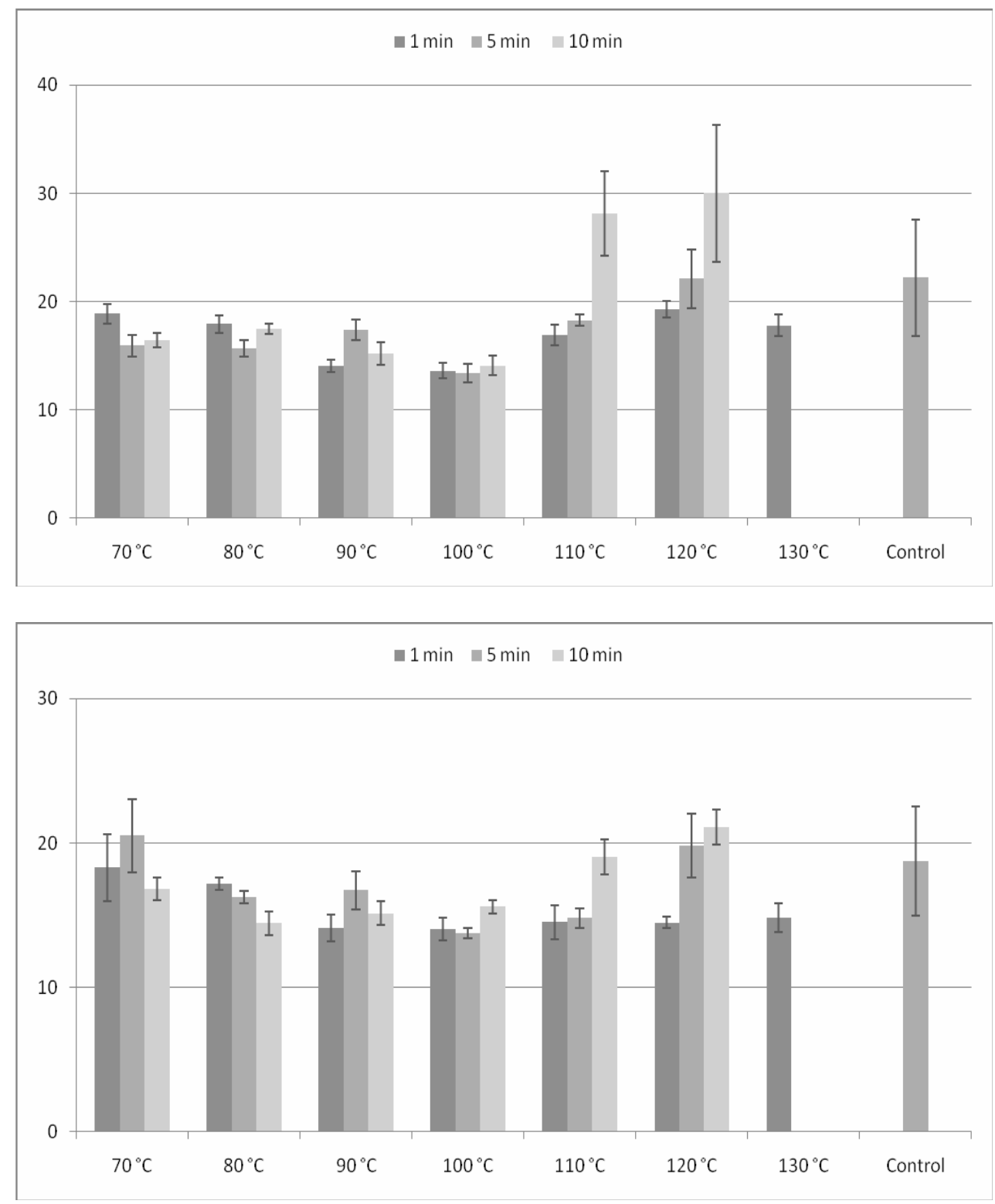

Figure 2. Cistus creticus: T 50 (days) in October (above) and March (below) trials. Error bars indicate the S.E. of means $(\mathrm{n}=4)$ 

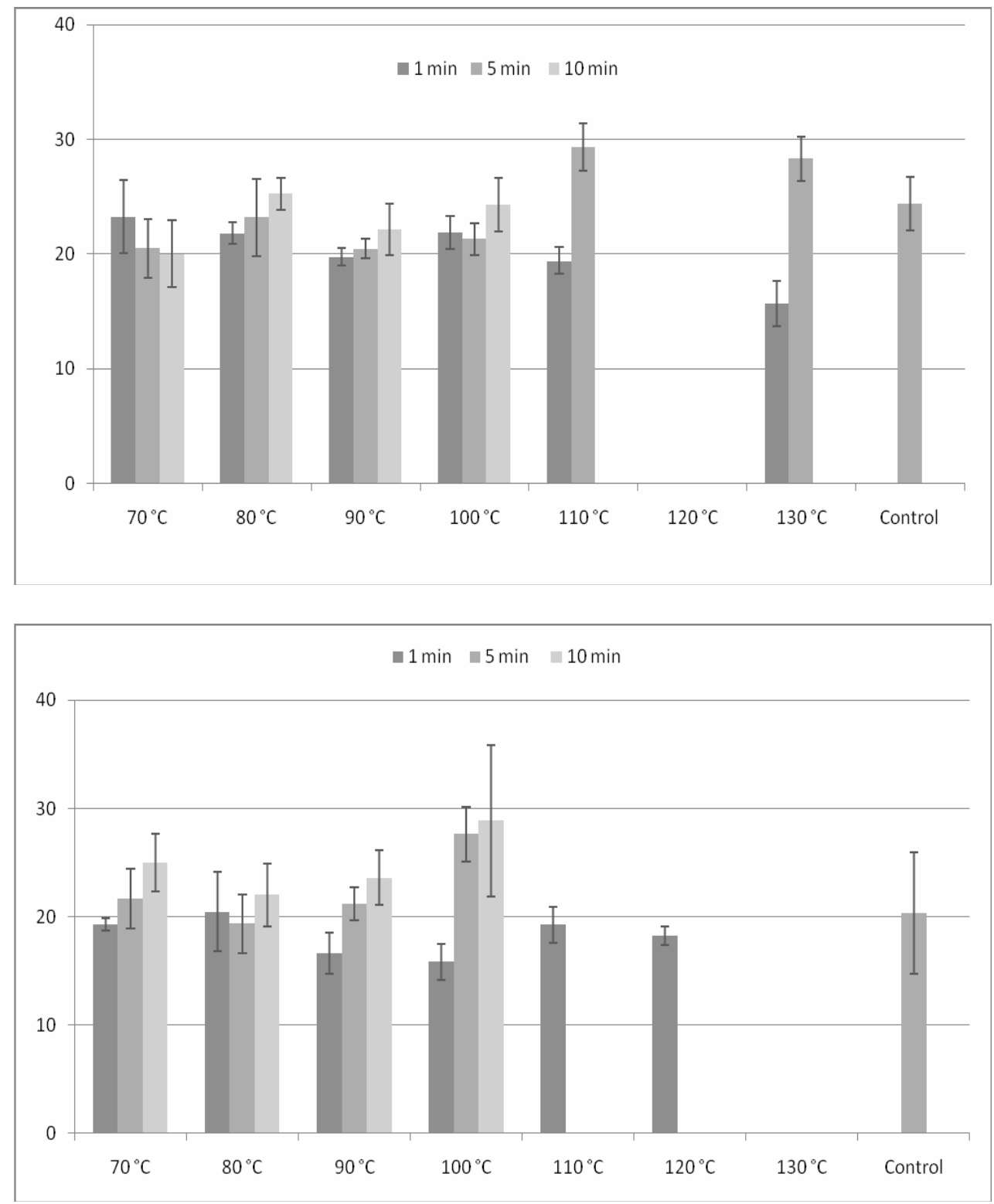

Figure 3. Cistus crispus: T 50 (days) in October (above) and March (below) trials. Error bars indicate the S.E. of means $(\mathrm{n}=4)$ 

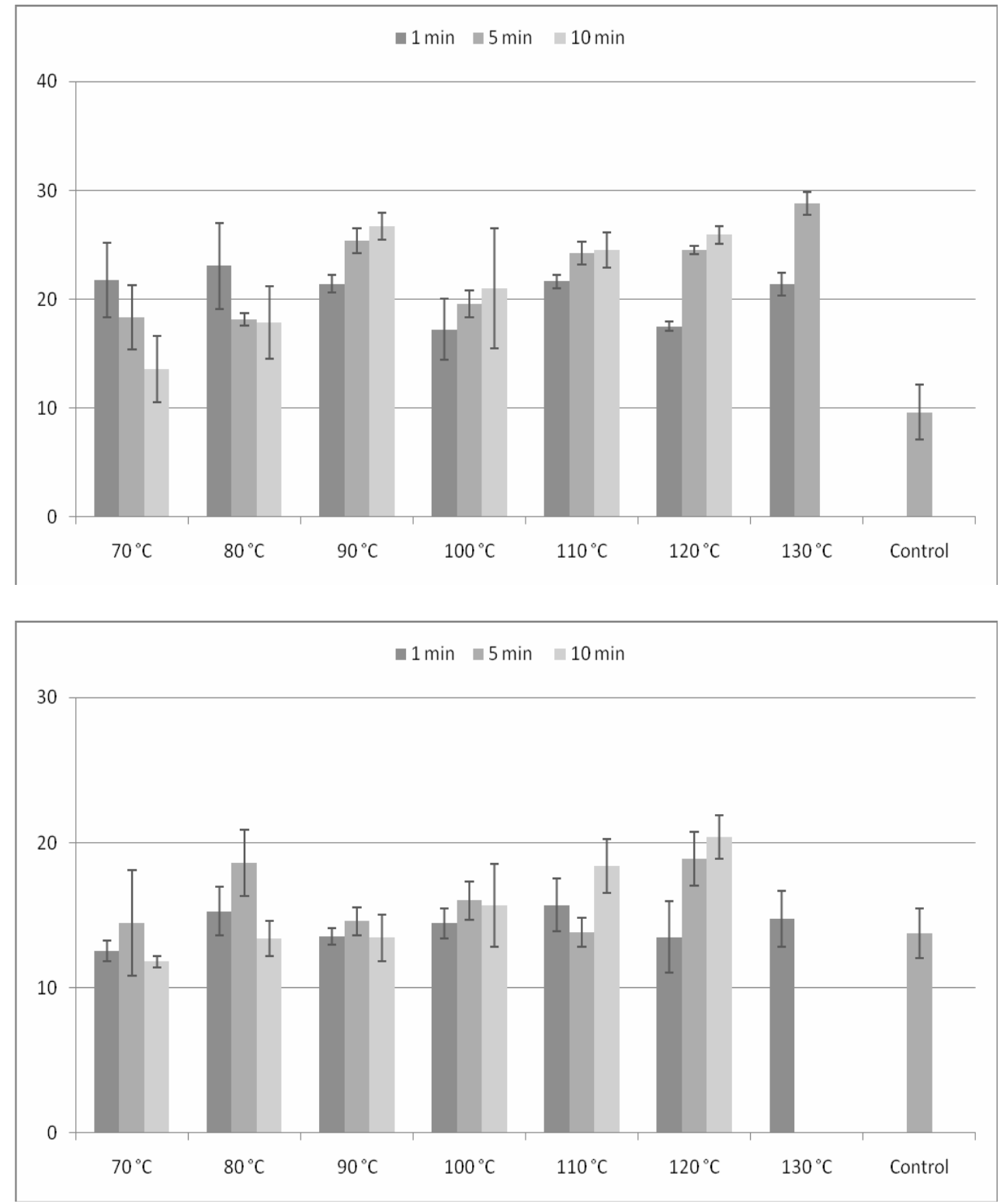

Figure 4. Cistus monspeliensis: T 50 (days) in October (above) and March (below) trials. Error bars indicate the S.E. of means $(n=4)$ 

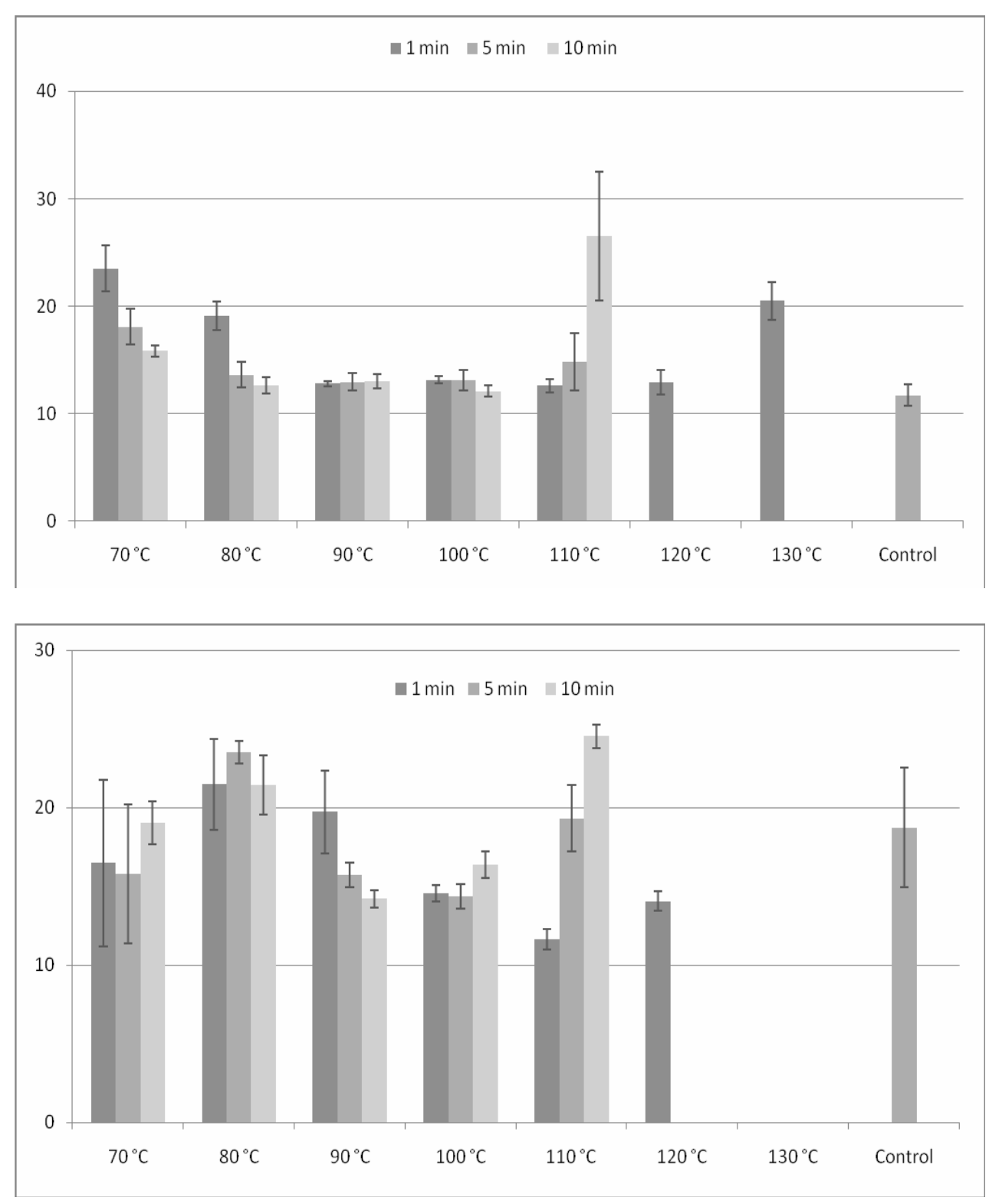

Figure 5. Cistus salviifolius: T 50 (days) in October (above) and March (below) trials. Error bars indicate the S.E. of means $(\mathrm{n}=4)$ 

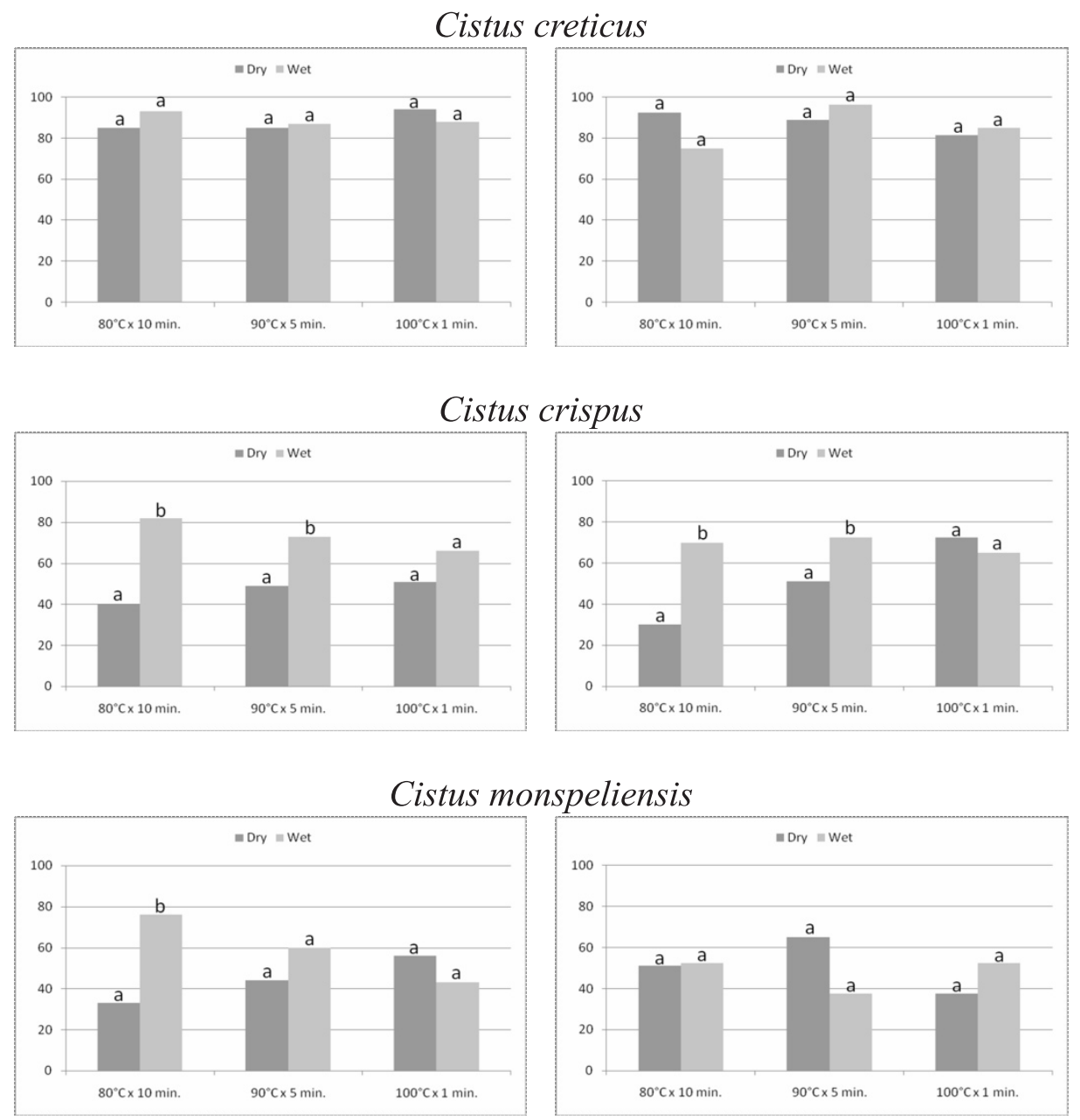

\section{Cistus salviifolius}
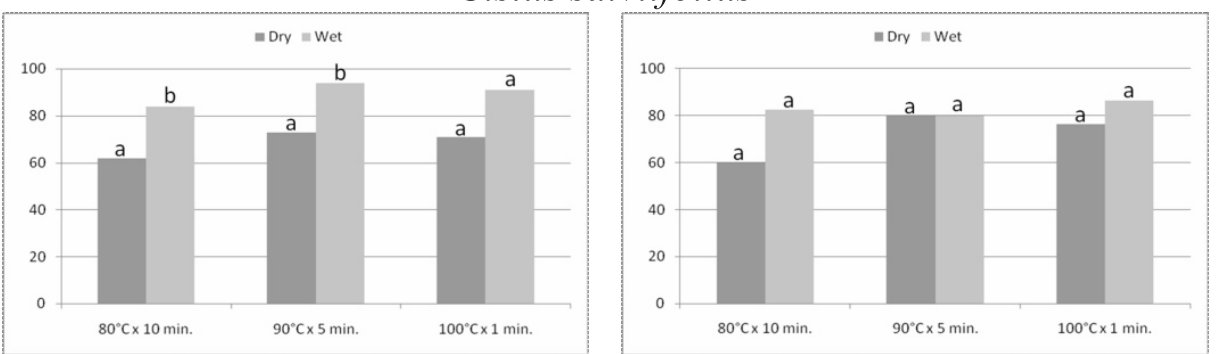

Figure 6. Seed germination (\%) in relation to treatments in the trial started in October (on the left) and in March (on the right). Significant differences between the treatments were shown at $\mathrm{P}<0.05$ by Student-Newman-Keuls test. Values with the same letter are not significant

\subsection{Experiment 2}

The seed immersion in distilled water at different temperatures (wet treatment) for various time enhanced the germination percentage in $C$. monspeliensis and $C$. salviifolius in the October trial, and particularly in C. crispus in both trials (Fig. 6).
This result can be linked to the ability of wet condition to stimulate the process (Bachetta et al. 2008). Also in this case there is a species-dependent response probably linked to the seed coat characteristics.

In all species any way was observed a drastic reduction of T50 values in relation to the wet treatment able to accelerate the mean time of germination (Fig. 7). 

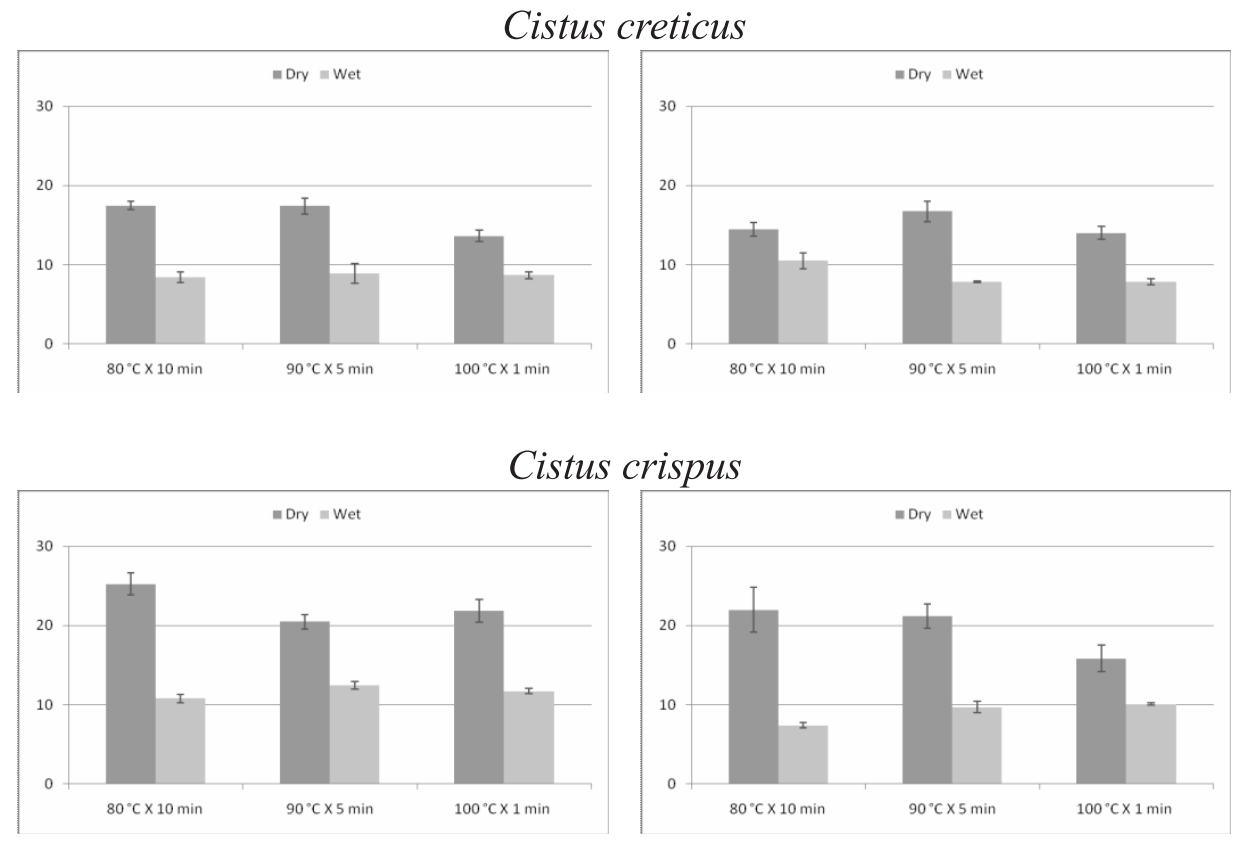

Cistus monspeliensis

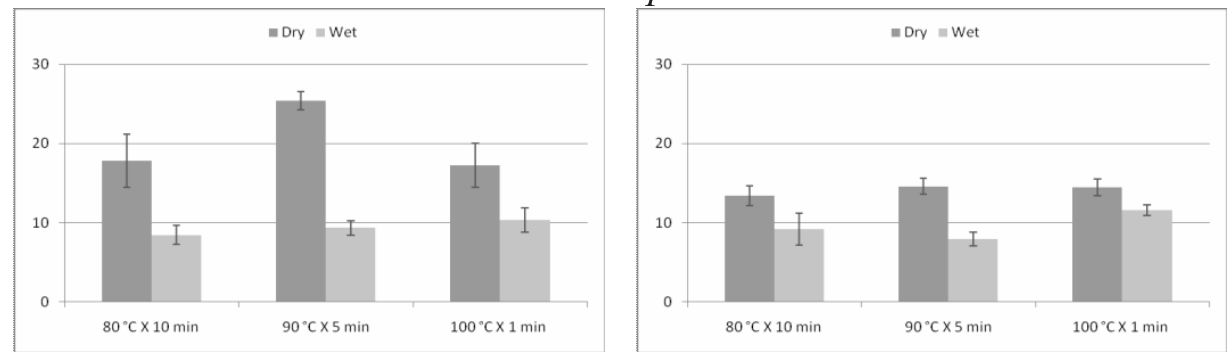

Cistus salviifolius

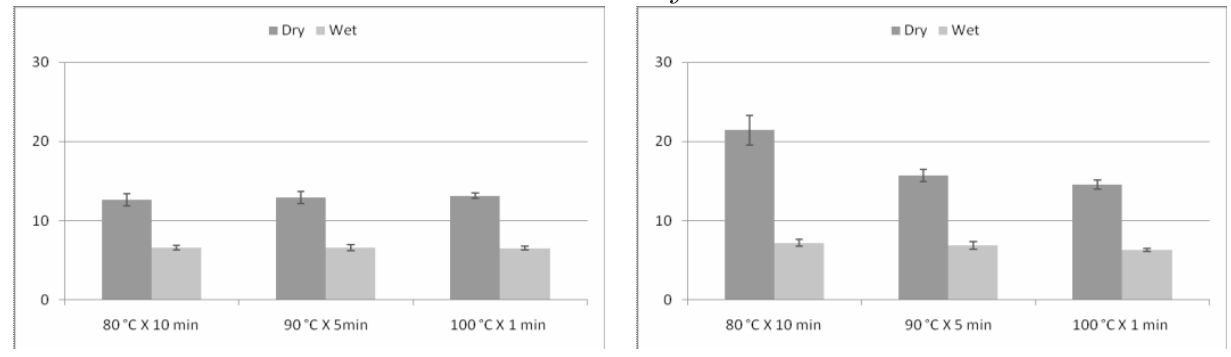

Figure 7. T 50 (days) in relation to treatments in the trial started in October (on the left) and in March (on the right). Error bars indicate the S.E. of means $(n=4)$ 
The achieved results allowed to better individuate the Cistus native species requirements for the germination. For all species the utility to use heat treatment to stimulate the germination was widely demonstrated. At the same time, the effects of heat are usually reflected in the germination level, but not in the germination rate. The fire is an important mechanism for Cistus species for colonising heterogeneous environments, especially in habitats degraded by recurrent fires.

\section{Acknowledgment}

This study was supported by REVFLOR project "Recupero e valorizzazione del patrimonio autoctono e naturalizzato: innovazione di prodotto in floricoltura".

\section{References}

Aronne G. \& De Micco V., 2001, Seasonal dimorphism in the Mediterranean Cistus incanus L. subsp. incanus, Annals of Botany 87: 789-794.

Bacchetta G., Casti M. \& Fanti D., 2008, Nuovi dati sulla biologia della germinazione di quattro specie del genere Cistus L. (Cistaceae) in Sardegna, 103 Congresso Società Botanica Italiana 173, Reggio Calabria.

Baskin J.M. \& Baskin C.C., 1989, Physiology of dormancy and germination in relation to seed bank ecology, 5366, [in:] M.A. Leck., V.T. Thomas and R.L. Simpson (eds.), Ecology of soil seed banks, Academic Press, San Diego, California.

Bastida F. \& Talavera S., 2002, Temporal and spatial patterns of seed dispersal in two Cistus species (Cistaceae), Annals of Botany 89: 427-434.

Come D., 1970, Les obstacles á la germination, Masson, Paris.

Daget P., 1977, Le bioclimat méditerranéen caractères generaux, mode de caracterisation, Vegetatio 34: 1-20.

Delgado J.A., Serrano J.M., López F. \& Acosta F.J., 2001, Heat shock, mass-dependent germination, and seed yield as related components of fitness in Cistus ladanifer, Environmental and Experimental Botany 46: 11-20.

Doussi M.A. \& Thanos C.A., 1994, Post-fire regeneration of hardseeded plants: ecophysiology of seed germination. Proc. 2nd International Conference Forest Fire Research, Vol. II: 1035-1044.

Ferrandis P., Herranz J.M. \& Martínez-Sánchez J.J., 1999, Effect of fire on hard-coated Cistaceae seed banks and its influence on techniques for quantifying seed banks, Plant Ecology 144: 103-114.

Ferrandis P., de las Heras J., Martínez-Sánchez J.J. \& Herranz J.M., 2001, Influence of a low-intensity fire on a Pinus halepensis Mill. forest seed bank and its consequences on the early stages of plant succession, Israel Journal of Plant Sciences 49: 105-114.

Giardina G., Raimondo F.M. \& Spadaro V., 2007, A catalogue of plants growing in Sicily, Bocconea 20, Herbarium Mediterraneum Panormitanum, Palermo.

Grime J.P., 1989, Seed banks in ecological perspectives, [in:] M.A. Leck, V.T. Parker R.L. Simpson (eds.) Ecology of soil seed banks, Academic Press, New York.

Guzman B. \& Vargas P., 2005, Systematics, character evolution, and biogeography of Cistus L. based on ITS, trnL-trnF, and matK sequences, Molecular Phylogenetics and Evolution 37: 644-660.

Guzman B., Vargas P., 2009, Historical biogeography and character evolution of Cistaceae (Malvales) based on analysis of plastid $r b c L$ and $t r n L-t r n F$ sequences, Organism, Diversity and Evolution 9: 83-99.

Hanley M.E. \& Fenner M., 1998, Pre-germination temperature and the survivorship and onward growth of Mediterranean fire-following plant species, Acta Oecologica 19(2): 181-187.

Herránz J.M., Ferrandis P. \& Martínez-Sánchez J.J., 2000, Influence of heat on seed germination of nine woody Cistaceae species, International Journal of Wildland Fire 9: 173-182.

Herrero C., San Martin R. \& Bravo F., 2007, Effect of heat and ash treatments on germination of Pinus pinaster and Cistus laurifolius, Journal of Arid Environments 70: $540-548$.

Kuhnholtz-Lordat G., 1938, La terre incendiée, Essai d'Agronomie Comparée, Maison Carée, Nimes.

Li Rosi A., Di Gregorio R. \& Romano D., 2008, La propagazione di alcune specie del genere Cistus L., VIII Convegno Nazionale sulla Biodiversità, Lecce, 21-23 April.

Núñez R. \& Calvo L., 2000, Effect of high temperatures on seed germination of Pinus halepensis and Pinus sylvestris, Forest Ecology and Management 131: 183-190.

Pérez F. \& Pita J.M., 1996, Ecofisiología de la germinación de las jaras (Cistus spp.), Lecciones hiperrtextuales de botánica, (revista@quercus.es).

Pérez-Garcia F., 1997, Germination of Cistus ladanifer seeds in relation to parent material, Plant Ecology 133: 57-62.

Piotto B. \& Di Noi A., 2001, Propagazione per seme di alberi e arbusti della flora mediterranea, A.N.P.A., Roma.

Quintana J.R., Cruz, A., Fernández-González F. \& Moreno J.M., 2004, Time of germination and establishment success after fire of three obligate seeders in a Mediterranean shrubland of central Spain, Journal of Biogeography 31: 241-249.

Reyes O. \& Boedo M., 2001, El fuego come controlador de la germinación de Cytisus striatus y de C. multiflorus 
y su aplicación agronómica, [in:] III Congreso Forestal Español, Mesa, vol. 6: 15-21, Granada.

Reyes O. \& Trabaud L., 2009, Germination behaviour of 14 Mediterranean species in relation to fire factors: smoke and heat, Plant Ecology 202: 113-121.

Salehzade H., Shishvan M.I., Ghiyasi M., Forouzin F. \& Siyahjani A.A., 2009, Effect of seed priming on germination and seedling growth of wheat (Triticum aestivum L.), Research Journal of Biological Science 4(5): 629-631.

Sousa W.P., 1984, The role of disturbance in natural communities, Annual Review of Ecology and Systematics 15: 353-391.

Specht R.L., 1987, The effect of summer drought on vegetation structure in the Mediterranean climate region of Australia, [in:] J.D. Tenhunen, F.M. Catarino, O.L. Lange, W.C.Oechel, (eds.), Plant response to stress - Functional analysis in Mediterranean ecosystem, NATO ASI Series, Springer-Verlag, Berlin: 625-640.

Talavera S., Gibbs P.E. \& Herrera J., 1993, Reproductive biology of Cistus ladanifer (Cistaceae), Plant Systematics and Evolution 186: 123-134.

Thanos C.A. \& Georghiou K., 1988, Ecophysiology of fire-stimulated seed germination in Cistus incanus ssp. creticus (L.) Heywood and C. salvifolius L., Plant Cell and Environment 11: 841-849.

Thanos C.A., Georghiou K., Kadis C. \& Pantazi C., 1992, Cistaceae: a plant family with hard seeds, Israel Journal of Botany 41: 251-263.
Thanos C.A., Marcou S., Christodoulakis D. \& Yannitsaros A., 1989, Early post fire regeneration in Pinus brutia forest ecosystem of Samos island (Greece), Acta Oecologica/Oecologia Plantarum 10(1): 79-94.

Thompson K. \& Booth R.E., 1993, Dormancy breaking, 187-190, [in:] G.A.F.Hendry, J.P. Grime (eds.), Methods in comparative plant ecology. A laboratory manual, Chapman \& Hall, London.

Trabaud L., 1979, Etude du comportement du feu dans la Garrige de Chene kermès à partir des températures et des vitesses de propagation, Annales des Sciences Forestières 36(1): 13-38.

Trabaud L., 1995, Modalités de germination des cistes et des pins méditerranéens et colonisation des sites pertubés, Revue Ecologie (Terre Vie) 50: 3-14.

Trabaud L., Michels C. \& Grosman J., 1985, Recovery of burnt Pinus halepensis Mill., forest. II Pine reconstitution after wildfire, Forest Ecology and Management 13: $167-179$.

Trabaud L. \& Renard P., 1999, Do light and litter influence the recruitment of Cistus spp. stands?, Israel Journal of Ecology \& Evolution 47: 1-9.

Troumbis A. \& Trabaud, L., 1986, Comparison of reproductive biological attributes of two Cistus species, Acta Oecologica/Oecologia Plantarum 7: 235-250.

Valbuena L., Tárrega R. \& Luis E., 1992, Influence of heat on seed germination of Cistus laurifolius and Cistus ladanifer, International Journal of Wildland Fire 2:15-20. 